\title{
Diversification as a Means of Achieving Sustainable Development Goal on Poverty Eradication: Evidence from Farm Households, Rural Nigeria
}

\author{
Abdulaziz Shehu*, Shaufique F. Sidique ${ }^{\#}$ \\ *Department of Economics, Federal University Birnin Kebbi, Nigeria \\ "Department of Economics, University Putra Malaysia
}

(Received 04 July 2018, accepted 02 April 2019)

https://doi.org/10.36224/ijes.120204

\begin{abstract}
High incidence of poverty in sub Saharan Africa and other parts of developing countries has clearly shown that that a lot have to be done towards the accomplishment of sustainable development goal (SDG) of poverty eradication by the year 2030. The objective of this study is to examine the effect of diversification on poverty reduction among farm households in rural Nigeria with a view to proffer possible suggestions on how to achieve sustainable development goal on poverty eradication by 2030. The study used per capita consumption expenditure as a measure of economic wellbeing as well as poverty status. Data on the third wave of the Nigerian General Household Survey (GHS) with a nationally representative sample of 3,256 panel rural households conducted by the Nigerian Bureau of Statistics in collaboration with the World Bank in 2015/2016 was used for the study which was analysed using propensity score matching approach. The matching results revealed that diversification has a positive and significant effect on the household wellbeing irrespective of their poverty status. However, diversification contributes more to the wellbeing of the non-poor households than the poor ones. In the light of the foregoing, the study recommends that sustainable development policies seeking to address rural poverty should not only consider agricultural development. They should also consider enhancing the ability of poor rural households to diversify into high return non-farm activities as it supplements their earnings from agriculture and have positive significant effect on their wellbeing. Further, there is need to encourage rural banking scheme with the simple collateral requirement as well as promote cooperative societies, educational programmes, non-farm enterprise activities and community infrastructures.
\end{abstract}

Keywords: Non-farm Diversification; Sustainable Development Goal; Poverty Reduction; Rural Household; Nigeria; Propensity Score matching Approx.

\section{Introduction}

Poverty alleviation has been part of the worldwide agenda since September, 2000 when the countries of the world signed the Millennium Declaration Goal (MDG) and set their commitment towards reducing poverty in the entire world to a minimum level by the end of the year 2015. The slow progress in the achievement of the Millennium Development Goals (MDGs) has made countries of the world to adopt a set of Sustainable Development Goals (SDGs) that target to end extreme poverty by the end of 2030.The SD shave been committed, as stated in its agenda, to build upon the achievements of the MDGs and seek to eradicate poverty in all its forms and dimensions. Meanwhile, high incidence of poverty in sub Saharan African other parts of developing countries has clearly shown that that poverty alleviation efforts of countries of the world has remained elusive, particularly in the rural areas. Arguably, the most significant gains of global poverty reduction has not been fully achieved. This necessitates the need to study alternative livelihood strategies that can effectivelydealt with the menace of poverty in the region and world in general towards attainment of sustainable development goal of poverty eradication. 
Non-farmdiversification has been commonly identified as one of the key livelihood strategies of rural households in developingcountries thatreduces household poverty [1 -5$]$. The sector captures about 30-51 percent of the income of rural households [6-8]. It also provides the householdswithin come generating opportunities that slows down rural-urban migration, income inequality and improve their poverty and food security status [5, 7, 9-12]. Despite mounting evidence on the role of non-farm diversification in improving household livelihood [11, 12, 13-17] little is known about its effect on their poverty status, particularly in Nigeria and other developing countries. This may be as a result of paucity of empirical studies on household poverty and endogeneity concern of non-farm diversification to household welfare. Further, most of the existing studies examinedpovertyat macro level which makes it difficult to suggest effective policies to promote diversification as a means of improving individual household wellbeing. Thus, to bring an end to the menace of poverty in the entire world, there is the need for adequate empirical studies on poverty at micro level as accurate poverty measurement and effective poverty reduction policies could best be achieved through micro level information to be gathered from household level studies $[2,17]$. The objective of this paper is to examine the effect of non-farm diversification on poverty reduction among rural households in Nigeria with a view to profferpossible suggestions at micro level on how to achieve sustainable development goal of poverty eradication. In the context of his study, non-farm diversification is measured by the share of the household members that diversified into self and wage employed activities carried out in the non-farm sector of the economy. Nigeria was chosen for the purpose of this study as it is one of the countries in thesub Saharan African region with high incidence of poverty and comprehensive recent and reliable data on non-farm diversification at household level. The study used the third wave of the nationallyrepresentative NigerianGeneral HouseholdSurvey (GHS) data of 3,256 panel rural households conducted in 2015/2016by the Nigerian Bureau of Statistics in collaboration with the World Bank for its analysis using propensity score matching approach.

The outcome of this study create a genuine opportunity for the development of evidence-based policies, strategies and programmes to achieve SDG 1 of poverty eradication through promoting non-farm diversification. To achieve the foregoing objective, the rest of the chapter is structured as follows. The next section provides a literature review. Section three presents the methodology. Section four discusses the empirical findings and the last section gives the conclusion and recommendations.

\section{Literature review}

Household utility theory captures the rationale behind diversification of farm households into non-farm activities. The theory was developed by Michael and Becker (1973) and later extended to farm households by Singh et al., (1986). Household utility theory emphasized on the role of marginal utility in determining household resource allocative decision into various form of income generating activities. In line with the theory, a household decides to allocate his time and resources into non-farm activities only if the expected marginal utility of nonfarm activity is either greater than or equal to the expected utility from farming. The theory maintains that rural households that diversify into non-farm activities tend to have a higher standard of living than those that have not diversify into such activities. The diversified ones earned income from both farm and non-farm activity, while undiversified households earn their income only from farm activity. The theory has been adapted by many empirical studies as the relevant behavioral model for studying issues related to farm households in developing countries. 
On the empirical literature, [18]revealed that income from non- farm activities have a larger effect on poverty reduction than agriculture in Nigeria, which is likely due to their overreliance on subsistence agriculture. In the same vein, [19] found that non-farm enterprise activities have a positive and significant effect on the wellbeing of households in Nigeria. [20] reaffirmed that that non-farm activities provide employment for the majority of young men and women, and family members in the east eastern Nigeria. He further reveals that women dominate non-farm business activities in the area. In a related development, [10] revealed that diversification to nonfarm livelihood strategies rather than relying only on subsistence farming enables householdsin Nigeria to have better incomes, enhance food security, increase agricultural production by smoothing capital constraints and also to better cope with environmental stress.

[3] also asserts that high return non-farm activities play a vital role in reducing poverty among households in Nepal. However, the involvement of poor households in these remunerative sectors are determined by various financial, social and human capitals.

Employing a recursive approach to examine the effects of diversification on household economic wellbeing in Burkina Faso, [6] reveal that diversification has a positive significant impact on the income and food consumption expenditure of the households. Similarly, [11] employs propensity matching approach to examine the effect of non-farm enterprise diversification on household wellbeing in rural Ethiopia by using household income and food security status of the household as the basis of measuring household wellbeing. The result shows that non-farm enterprise diversification has a positive significant impact on the household wellbeing by all measures.

From the foregoing literature, it is clear that that studieson the effect of non-farm diversification on wellbeing of households in developing countries are far from conclusive. The existing studies tend to have mixed findings, which vary with location, time and the specific context of the study. Moreover, there are few studies in the literature that examined the causal relationship that exists between non-farm diversification and household welfare. Therefore, further empirical evidences are still needed to justify the impact of non-farm diversification on the economic wellbeing of rural households in developing countries towards attainment of sustainable development goal of poverty eradication by the year 2030 .

\section{Methodology}

\subsection{Scope of the study}

The study focused on the role of non-farm diversification in reducing poverty among rural households in Nigeria with a view to suggest effective policies to achieve SDGtarget of poverty eradication. The country is relatively the most populous country in the region with approximately 163 million people and high incidence of poverty (NBS, 2010)

\subsection{Source of data}

Data for this study was obtained from the third wave of the nationally representative General Household Panel Survey carried out by the Nigerian Bureau of Statistics in collaboration with the World Bank in 2015/2016. The survey was designed in accordance with the World Bank Living Standards Measurement Surveys (LSMS) and covered information on all aspects of household living conditions. 


\subsection{Sample Size of the survey}

The sample size of the survey is designed to be representative of the urban and rural households at the national and the zonal levels. The survey used a comprehensive list of all the enumeration areas (EAs) in Nigeria together with their respective population as its sampling frame. As this study focused on rural households, the study utilised only the total rural sample of 3360 for its analysis.

\section{Results and discussion}

\subsection{Descriptive statistics}

The descriptive statistics presented in Table 1 indicates that about $65 \%$ of the households are poor and $35 \%$ are non-poor ones. This is almost the same with the current Nigerian poverty statistics.

Table 1: Descriptive statistics

\begin{tabular}{|c|c|c|c|c|c|c|c|c|}
\hline \multirow[t]{2}{*}{$\begin{array}{l}\text { Variable } \\
\text { Description }\end{array}$} & \multirow[t]{2}{*}{ Unit } & \multicolumn{2}{|c|}{$\begin{array}{c}\text { All the } \\
\text { Households }\end{array}$} & \multicolumn{2}{|c|}{$\begin{array}{c}\text { Non-poor } \\
\text { Households } \\
(35 \%)\end{array}$} & \multicolumn{2}{|c|}{$\begin{array}{c}\text { Poor } \\
\text { Households } \\
(65 \%)\end{array}$} & \multirow[t]{2}{*}{$\begin{array}{c}\text { T-test } \\
\text { (Means } \\
\text { Difference) }\end{array}$} \\
\hline & & Mean & $\mathrm{SD}$ & Mean & SD & Mean & $\mathrm{SD}$ & \\
\hline $\begin{array}{l}\text { Per capita household } \\
\text { consumption } \\
\text { expenditure }\end{array}$ & $\#(0000)$ & 70890 & 66998 & 131252 & 80965 & 37973 & 17102 & $93279^{* * *}$ \\
\hline Non-farm Diversification & Count & 0.23 & 0.28 & 0.31 & 0.33 & 0.18 & 0.23 & $0.13^{* * *}$ \\
\hline \multicolumn{9}{|l|}{ Household Characteristics } \\
\hline Gender & $1 / 0$ & 0.86 & 0.33 & 0.81 & 0.38 & 0.89 & 0.30 & -0.07 \\
\hline Age of Head & Years & 49.87 & 15.25 & 49.54 & 15.65 & 50.06 & 15.02 & -0.52 \\
\hline Age of Head Square & Years & 2720 & 1634 & 2699 & 1661 & 2731 & 1619 & -32.00 \\
\hline Education & Years & 3.40 & 3.72 & 5.10 & 4.43 & 2.47 & 2.87 & $2.63^{* * *}$ \\
\hline Education Square & Years & 25.47 & 49.64 & 45.78 & 70.79 & 14.40 & 27.00 & $31.38^{* * *}$ \\
\hline Adults $\quad(\%)$ & Years & 0.61 & 0.16 & 0.59 & 0.29 & 0.62 & 0.15 & -0.03 \\
\hline Dependents (\%) & Years & 0.39 & 0.11 & 0.41 & 0.10 & 0.38 & 0.13 & 0.03 \\
\hline Farm Size & Hectares & 1.65 & 1.18 & 1.58 & 1.16 & 1.25 & 1.15 & -0.33 \\
\hline \multicolumn{9}{|l|}{ Entry Barriers } \\
\hline Formal Credit (\%) & Count & 0.08 & 0.18 & 0.13 & 0.26 & 0.05 & 0.13 & $0.08^{* * *}$ \\
\hline Social Capital (\%) & Count & 0.05 & 0.16 & 0.09 & 0.22 & 0.03 & 0.10 & $0.06^{* * *}$ \\
\hline Proximity to Market & $\mathrm{Km}$ & 4.09 & 7.32 & 2.81 & 5.89 & 4.79 & 7.91 & $-1.98^{* * *}$ \\
\hline \multicolumn{9}{|c|}{ Community Infrastructures } \\
\hline Mobile Phone & $1 / 0$ & 0.14 & 0.35 & 0.16 & 0.36 & 0.14 & 0.34 & 0.02 \\
\hline Electricity & $1 / 0$ & 0.20 & 0.40 & 0.27 & 0.44 & 0.16 & 0.37 & $0.11^{* * *}$ \\
\hline Public Transport & $1 / 0$ & 0.55 & 0.49 & 0.57 & 0.49 & 0.54 & 0.49 & 0.03 \\
\hline North & $1 / 0$ & 0.58 & 0.49 & 0.47 & 0.49 & 0.64 & 0.47 & $-0.17^{* * *}$ \\
\hline
\end{tabular}

The study disaggregated the sample into poor and non-poor households on the basis of theInternational world absolute poverty line at the time when the data was collected, which was $\$ 1.25$ dollar per day. The poverty line was further adjusted using the Consumer Price Index (CPI) so as to capture seasonal and regional variations of the household expenditure. It was further multiplied by the effective exchange rate of 2015, which stood at NGN200 per 
USD1as at the time of the survey to arrive atan annual poverty line of NGN 96,292, which is equivalent to USD481 dollars per annum. Thus, households whose per capita annual household consumption expenditure is less than NGN 96,292 are classified as poor and nonpoor otherwise.

Regarding household welfare, the t-test presented in the Table indicates that the mean of per capita annual consumption expenditure of non-poor households is higher than that of poor households. However, the study cannot rely on mean differences as the basis of assessing the effect of diversification on household welfare as it did not account for the differences in the characteristics of the poor and the non-poor households. The result of t-test presented in the descriptive indicates that there are differences between the poor and nonpoor households with respect to their educational status, family size and access to credit. Despite the level of education in rural parts of the country is very low having less than average of 5 years, the result indicates that the non-poor households are more educated than the poor ones. This portrays the importance of household wealth in influencing their educational attainment.

On average, the non-poor farm households are having smaller and manageable family size than the poor ones. The proportion of non-poor households with access to social as well as financial capital and community level infrastructures outweighs that of poor households. This indicates the importance of capital endowments, social networking and infrastructures to improvement in household welfare. The means of access to formal credit revealed that the share of non-poor households that use formal credit is higher than that of the poor ones. This portrayed the inability of the poor households to have the necessary collateral needed for loan from formal financial institutions to invest in high return non-farm activities.

\subsection{Effect of non-farm diversification on poverty reduction}

The study first runs Probit model as it is the prerequisite of conducting propensity score analysis of the effect of non-farm diversification on poverty reduction. The essence of Probit model is to determine the factors influencing household non-farm diversification decision and propensity score estimates that will balance the observed distribution of the covariates across the diversified and undiversified households in the sample.

The result of the Probit models presented in Table 1 shows that the household head age, household size, formal credit, social capital, community level infrastructures and regional location are having a positive and significant effect on diversification decision. The common support condition was imposed in all the estimated Probit regression models to ensure that the balancing property was satisfied. The result of the distribution of propensity scores depicted in Figure 1 clearly show that the distribution of the conditioning covariates did not differ across the diversified and undiversified households in the matched samples.

The indicators of matching quality presented in Figure 1 and Table 1 confirm that there are no pre-diversification differences between the diversified and undiversified households in the sample. The result shows a substantial reduction in absolute bias in the outcomevariable. The mean bias of the covariates $\mathrm{Z}$ after matching lies below the $20 \%$ level of bias reduction. This indicates that the self-selection bias has been removed and the matching requirement has been satisfied. 
Table 2: Probit estimates of propensity score matching analysis dependent variable: non-farm diversification decision

\begin{tabular}{|c|c|c|c|}
\hline Variables & $\begin{array}{c}\text { All HHs } \\
\text { Coefficient }\end{array}$ & $\begin{array}{c}\text { Non-poor HHs } \\
\text { Coefficient }\end{array}$ & $\begin{array}{c}\text { Poor HHs } \\
\text { Coefficient }\end{array}$ \\
\hline \multicolumn{4}{|c|}{ Household Characteristics } \\
\hline Gender & $\begin{array}{c}0.10 \\
(0.73)\end{array}$ & $\begin{array}{c}0.05 \\
(0.11)\end{array}$ & $\begin{array}{c}0.09 \\
(0.10)\end{array}$ \\
\hline Age of Head & $\begin{array}{l}0.03^{* * * *} \\
(0.01)\end{array}$ & $(0.01)^{0.05^{* * *}}$ & $\begin{array}{l}0.04^{* * * *} \\
(0.01)\end{array}$ \\
\hline Age of Head square & $\begin{array}{l}-0.03^{* * *} \\
(0.01)\end{array}$ & $\begin{array}{l}-0.03^{* * *} \\
(0.01)\end{array}$ & $\begin{array}{l}-0.02^{*} \\
(0.01)\end{array}$ \\
\hline Adult & $\begin{array}{l}0.04^{* * * *} \\
(0.01)\end{array}$ & $\begin{array}{l}0.04^{* *} \\
(0.02)\end{array}$ & $\begin{array}{c}0.01 \\
(0.01)\end{array}$ \\
\hline Dependents & $\begin{array}{c}-0.11^{* * * *} \\
(0.02)\end{array}$ & $\begin{array}{l}-0.07^{*} \\
(0.04)\end{array}$ & $\begin{array}{c}-0.09^{* * * *} \\
(0.02)\end{array}$ \\
\hline Education & $\begin{array}{l}0.05^{* * * *} \\
(0.01)\end{array}$ & $\begin{array}{l}0.04^{* * *} \\
(0.01)\end{array}$ & $\begin{array}{l}0.05^{* * *} \\
(0.01)\end{array}$ \\
\hline Farm size & $\begin{array}{l}0.01 \\
(0.04)\end{array}$ & $\begin{array}{c}0.01 \\
(0.01)\end{array}$ & $\begin{array}{c}0.01 \\
(0.01)\end{array}$ \\
\hline Formal Credit & $\begin{array}{l}0.02^{* *} \\
(0.01)\end{array}$ & $\begin{array}{l}0.02^{* *} \\
(0.01)\end{array}$ & $\begin{array}{l}0.02^{* *} \\
(0.01)\end{array}$ \\
\hline Social Capital & $\begin{array}{l}0.07^{* * * *} \\
(0.02)\end{array}$ & $\begin{array}{l}0.03 * * \\
(0.01)\end{array}$ & $\begin{array}{l}0.09^{* * * *} \\
(0.04)\end{array}$ \\
\hline \multicolumn{4}{|c|}{ Community Infrastructures } \\
\hline Market proximity & $\begin{array}{l}-0.23^{* * *} \\
(0.03)\end{array}$ & $\begin{array}{l}-0.20 * * * \\
(0.06)\end{array}$ & $\begin{array}{l}-0.01^{* * * *} \\
(0.04)\end{array}$ \\
\hline Mobile Phone & $\begin{array}{c}0.25 \\
(0.06)\end{array}$ & $\begin{array}{l}0.02^{* *} \\
(0.01)\end{array}$ & $\begin{array}{l}0.33^{* * *} \\
(0.88)\end{array}$ \\
\hline Electricity & $\begin{array}{l}0.15^{* * * *} \\
(0.06)\end{array}$ & $\begin{array}{c}0.07 \\
(0.09)\end{array}$ & $\begin{array}{l}0.22^{* * * *} \\
(0.08)\end{array}$ \\
\hline Public Transport & $\begin{array}{c}0.01 \\
(0.04)\end{array}$ & $\begin{array}{c}0.08 \\
(0.08)\end{array}$ & $\begin{array}{l}0.14^{* *} \\
(0.05)\end{array}$ \\
\hline \multicolumn{4}{|l|}{ Regional Location } \\
\hline North & $\begin{array}{l}0.23^{* * *} \\
(0.05)\end{array}$ & $\begin{array}{c}0.05 \\
(0.09)\end{array}$ & $\begin{array}{l}0.21^{* * *} \\
0.07\end{array}$ \\
\hline Observations & 3257 & 1150 & 2107 \\
\hline Wald Test & $297^{* * *}$ & $186^{* * *}$ & $213^{* * *}$ \\
\hline Pseudo $\mathrm{R}^{2}$ & 0.18 & 0.14 & 0.16 \\
\hline Log Likelihood & -2087 & -704 & -1329 \\
\hline
\end{tabular}

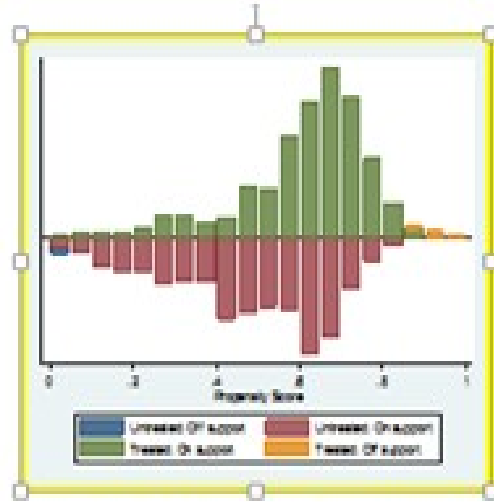

ALL HOUSEHOLDS

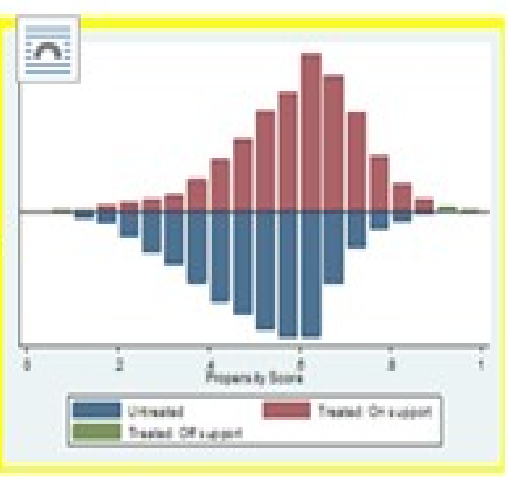

NON POOR HOUSEHOLDS

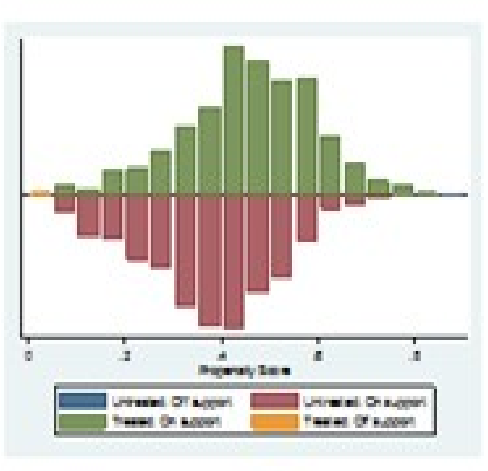

POOR HOUSEHOLDS

Figure 1: Distribution of propensity scores for matched sample 
Table 3: Indicators of matching quality before and after matching

\begin{tabular}{ccccccc}
\hline Treatment & $\begin{array}{c}\text { Outcome } \\
\text { Indicators }\end{array}$ & $\begin{array}{c}P \text {-Value } \\
(\text { Unmatched) }\end{array}$ & $\begin{array}{c}P \text {-Value } \\
(\text { Matched) }\end{array}$ & $\begin{array}{c}\text { Mean } \\
\text { Absolute } \\
\text { bias } \\
\text { Unmatched) }\end{array}$ & $\begin{array}{c}\text { Mean } \\
\text { Absolute } \\
\text { bias } \\
\text { Matched }\end{array}$ & $\begin{array}{c}\text { Absolute } \\
\text { bias } \\
\text { Reduction }\end{array}$ \\
\hline $\begin{array}{c}\text { All } \\
\text { Households }\end{array}$ & $\begin{array}{c}\text { Per capita HH } \\
\text { consumption } \\
\text { expenditure }\end{array}$ & 0.00 & 0.24 & 22.35 & 10.80 & 51.64 \\
$\begin{array}{c}\text { Non-Poor } \\
\text { Households }\end{array}$ & $\begin{array}{c}\text { Per capita HH } \\
\text { consumption } \\
\text { expenditure }\end{array}$ & 0.00 & 0.16 & 14.59 & 7.56 & 48.13 \\
Poor & $\begin{array}{c}\text { Per capita HH } \\
\text { consumption } \\
\text { expenditure }\end{array}$ & 0.00 & 0.13 & 33.18 & 22.89 & 31.01 \\
\hline \hline
\end{tabular}

The estimated result of average treatment effect on the treated (ATT) using radius matching technique presented in Table 4 shows that diversification has a positive and significant effect on the economic wellbeing of the rural households irrespective of their poverty status. However,the estimates of the average treatment effect on the treated for the entire sample indicates that those that diversified into non-farm activities have on average higher per capita annual household consumption expenditure of NGN21,886 (USD140) than those that have not diversified into non-farm activities. This finding demonstrates that household that diversifies into non-farm activities are better off than those that depend solely on farming as a means of sustaining their livelihood. However, after disaggregating the sample into poor and non-poor households it gives a different result. The magnitude of increase in per capita annual household consumption expenditure of diversified non-poor household is higher than that of diversified poor households by more than $400 \%$.

Table 4: Average treatment effect: radius matching

\begin{tabular}{|c|c|c|c|c|c|c|}
\hline \multirow[t]{2}{*}{ Treatment } & \multirow{2}{*}{$\begin{array}{l}\text { Outcome } \\
\text { Indicators }\end{array}$} & \multirow{2}{*}{ ATT } & \multicolumn{2}{|c|}{ Treated } & \multicolumn{2}{|c|}{ Control } \\
\hline & & & On Support & Off Support & On Support & Off Support \\
\hline $\begin{array}{c}\text { All } \\
\text { Households }\end{array}$ & $\begin{array}{c}\text { Per Capita HH } \\
\text { Consumption } \\
\text { Expenditure }\end{array}$ & $\begin{array}{c}21886^{* * *} \\
(2024)\end{array}$ & 1804 & 10 & 1443 & - \\
\hline $\begin{array}{r}\text { Non-Poor } \\
\text { Households }\end{array}$ & $\begin{array}{c}\text { Per Capita HH } \\
\text { consumption } \\
\text { expenditure }\end{array}$ & $\begin{array}{c}18975^{* * *} \\
(4105)\end{array}$ & 632 & 8 & 506 & 4 \\
\hline $\begin{array}{c}\text { Poor } \\
\text { Households }\end{array}$ & $\begin{array}{c}\text { Per capita HH } \\
\text { Consumption } \\
\text { expenditure }\end{array}$ & $\begin{array}{c}3701^{* * * *} \\
(910)\end{array}$ & 856 & 1 & 1249 & 1 \\
\hline
\end{tabular}

Note: Standard errors are reported in parenthesis

Household consumption expenditure is in Naira (NGN). 
Exchange rate as of 2015 is USD1 $=$ NGN156, *,**,*** represent $10 \%, 5 \%$ and $1 \%$ level of significance

Table 5: Treatment effects: sensitivity of matching algorithms

Kernel \& neighbor matching

\begin{tabular}{|c|c|c|c|c|c|c|}
\hline \multirow[t]{2}{*}{ Treatment } & \multirow{2}{*}{$\begin{array}{l}\text { Outcome } \\
\text { Indicators }\end{array}$} & \multirow{2}{*}{$\begin{array}{c}\text { ATT } \\
\text { \# }\end{array}$} & \multicolumn{2}{|c|}{ Treated } & \multicolumn{2}{|c|}{ Control } \\
\hline & & & On Suppc & ipport & On Suppo & pport \\
\hline $\begin{array}{c}\text { All } \\
\text { Households }\end{array}$ & $\begin{array}{l}\text { Per capita HH } \\
\text { consumption } \\
\text { expenditure }\end{array}$ & $\begin{array}{c}19480^{* * *} \\
(3104)\end{array}$ & 1804 & 10 & 1443 & - \\
\hline $\begin{array}{l}\text { Non-Poor } \\
\text { Households }\end{array}$ & $\begin{array}{l}\text { Per capita HH } \\
\text { consumption } \\
\text { expenditure }\end{array}$ & $\begin{array}{c}15052^{* * *} \\
(4813)\end{array}$ & 632 & 8 & 506 & 4 \\
\hline $\begin{array}{c}\text { Poor } \\
\text { Households }\end{array}$ & $\begin{array}{l}\text { Per Adult HH } \\
\text { consumption }\end{array}$ & $\begin{array}{l}3683^{* * *} \\
(889)\end{array}$ & 856 & 1 & 1249 & 1 \\
\hline & & Neighb & Iatching & & & \\
\hline $\begin{array}{c}\text { All } \\
\text { Households }\end{array}$ & $\begin{array}{c}\text { Per capita HH } \\
\text { consumption } \\
\text { expenditure }\end{array}$ & $\begin{array}{l}18714 \\
(2749)\end{array}$ & 1804 & 10 & 1443 & - \\
\hline $\begin{array}{l}\text { Non-Poor } \\
\text { Households }\end{array}$ & $\begin{array}{l}\text { Per capita HH } \\
\text { consumption } \\
\text { expenditure }\end{array}$ & $\begin{array}{l}13136 \\
(5060)\end{array}$ & 632 & 8 & 506 & 4 \\
\hline $\begin{array}{c}\text { Poor } \\
\text { Households }\end{array}$ & $\begin{array}{l}\text { Per capita HH } \\
\text { consumption } \\
\text { expenditure }\end{array}$ & $\begin{array}{c}3512^{* * *} \\
(820)\end{array}$ & 856 & 1 & 1249 & 1 \\
\hline
\end{tabular}

Note: Standard errors are reported in parenthesis

Household consumption expenditure is in Naira (NGN).

Exchange rate as of 2015 is USD1 $=$ NGN200

$*, * *, * * *$ represent $10 \%, 5 \%$ and $1 \%$ level of significance

The fact that the result revealed that diversification is more welfare enhancing for the non-poor households, but it still confirms the relevance of non-farm diversification in contributing to the improvement in the poverty status of the poor- households. The likely reason why the non-poor households are having lower earnings from non-farm activities is that they are limited to low return activities carried out in the non-farm sector of the economy due to low level of their income couple with low level of education and lack of access to formal credit.

To confirm if the radius matching result obtained in Table 4 is robust to other matching methods, the study performed sensitivity analysis using Nearest Neighbor and Kernel Gaussian matching techniques. The result of sensitivity matching analysis presented in Table 5 confirms that radius matching result is quite robust, and is not sensitive to other matching techniques. Although the result of radius matching method is consistent with other methods but it is slightly higher than that of other techniques.

\section{Conclusion and recommendations}

The study empirically examined the effect of non-farm diversification on the economic wellbeing of both poor and non-poor households in rural Nigeriawith a view to recommend possible suggestions on how to attain Sustainable Development Goal (SDG) of poverty eradication by 2030 through the development of non-farm sector. The propensity scare matching results revealed that diversification has a positive and significant effect on the economic wellbeing of the households irrespective of their poverty status. However, the results indicated that diversification contributes more to the improvement in the wellbeing of the non-poor households than the poor ones.In the light of foregoing, the studysuggest the 
following recommendations towards attaining sustainable development goal of poverty eradication by 2030 .

i. Policies seeking to address poverty should go beyond agricultural development. They should also consider enhancing the ability of rural households to diversify into high return non-farm activities as it supplements their earnings from agriculture and have positive significant effect on their wellbeing. This can be facilitated by increasing poor household access to formal credit through introducing the rural banking scheme with the simple collateral requirement.

ii. The government should also introduce a scheme that trained the rural people on how to utilize their local resources for non-farm businesses.

iii. Associations such as cooperatives, women's associations and business associations should also be encouraged among the rural households as they plays vital roles in influencing rural diversification.

iv. Rural households should also be equipped with basic formal education by introducing programs such as free basic education and adult education in rural areas.

$\mathrm{v}$. The significance of community level infrastructures in influencing diversification signifies that the government should ensure that they provided adequate infrastructures in the rural communities

\section{References}

1. Ellis, F.,The determinants of rural livelihood diversification in developing countries, Journal ofAgricultural Economics ,2002,51, 289-302

2. Christiaensen, L and Kaminski, J.,Structural change, economic growth and poverty reduction. Micro Evidence from Ugandat; Working paper African Development Bank.,2016,216

3. Gautam, Y. and Andersen, P., Rural livelihood diversification and household well-being: Insights from Humla, Nepal, Journal of Rural Studies,44 (2016),239-249

4. Ravallion, M., Are the world poorest being left behind?. Journal of Economic Growth, 21(139)

5. FAO, End poverty in all its forms everywhere, Poverty Eradication Sustainable Development Goals and post development agenda: www.fao.org sustainable-development-goals,2018

6. Reardon, T., Delgado, T.C. and Malton, P. \&quot; Determinants and effects of income diversification among farm households in Burkina Faso \& quot;.Journal of Development studies, 1992,289,264-296.

7. Haggblade, S., Hazell, P. and Reardon, T, \&quot; The rural non-farm economy: prospects for growth and poverty reduction \& quot; World Development, 2010,38,1429-1441

8. National Bureau of Statistics, "Nigerian General Household Survey: Basic Information Document", Abuja Nigeria, 2012.

9. Lanjouw, J.O. and Lanjouw, P., "The rural non-farm sector issues and evidences", Agricultural Economics, 2001, 26, 1-23

10. Babatunde, R. O. and Qaim, M. \&quot; Impact of off-farm income on food security and nutrition in Nigeria \& quot;,Food Policy,2010,35,303-311

11. Ali, M. and Peerlings, J. \&quot; Farm households and non-farm activities in Ethiopia: does clustering influence entry and exit ?",Agricultural Economics,2012,43,253-266.

12. IFAD. \& quot; Rural Development Report International Fund for Agriculture and Development:2016.

13. Reardon, T., "Using evidence of household income diversification to inform study of the rural non-farm labor market in Africa", World Development, 1997, 25, 735-747.

14. Abdulai, A. and Crolerees, A, \&quot; Determinants of income diversification amongst rural households in Southern Mali \& quot;,, Food Policy,2010, 26,437-452.

15. Sekumade, A.B and Osundare, F.O . Determinants and Effect of Livelihood Diversification on Farm Households in Ekiti State, Nigeria. Journal of Economics and Sustainable Development 2014, 5, 5 .

16. Christiaensen, L and Yasuyiki, T., Poverty reduction during the rural urban transformation - The role of missing middle. World Development 2014, 63(C): 43-58. 
17. De Janvry, A. and Sadoulet, E., Achieving sustainable development goal of poverty eradication. Working paper, Development policies, FERDI, 2017.

18. Oseni, G. , Nigeria agriculture and rural poverty. A policy note published in World Bank report on Poverty reduction and economic management African region, Washington DC, 2014.

19. Shehu, A. and Shaufique, F.S., A propensity score matching analysis of the impact of participation in non-farm enterprise activities on household wellbeing in rural Nigeria. UMK Procedia 2014, 1, $26-32$.

20. Igwe, P.A, "Rural Non-farm Livelihood Diversification and Poverty Reduction in Nigeria", Ph.D. Thesis, Business School, Plymouth University United Kingdom, 2013. 